\title{
SOSIALISASI PERAN UMKM DAN PERATURAN PEMERINTAH NOMOR 23 TAHUN 2018 GUNA MENDORONG MASYARAKAT SADAR PAJAK
}

\author{
Amir Hidayatulloh*, Fina Dwi Fatma \\ Fakultas Ekonomi dan Bisnis, Universitas Ahmad Dahlan \\ Jl. Kapas Nomor 9, Semaki, Umbulharjo, Kota Yogyakarta \\ email: amir.hidayatulloh@act.uad.ac.id
}

\begin{abstract}
Tax is the main source of state revenue. In 2018, the source of state revenues of 85,40\% came from the tax sector. So large, state revenue from tax sector, encourage the government in increase taxpayer compliance. However, the realization of revenue from the tax sector in January-November has not yet reached the target. In 2018, the government issued a government regulation that was imposed on taxpayers who have certain gross income. So, with the issuance of government regulation it is hoped that the public can play an active role in economic activities. This service was carried out in Banjaran Hamlet, Sukoreno, Sentolo, Kulon Progo, Special Regional of Yogyakarta. This service is shown to MSME players. This service technique uses lecture, sharing and discussion methods. The result of this service activity is to increase the knowledge of MSME actors regarding the benefits of NPWP, the reason MSME actors must pay taxes, and tax benefits. In addition, this service also found the reason for MSME not to make NPWP, as well as the reason for MSME actors not to apply Government Regulation Number 23 of 2018. In addition, MSMEs did not understand the importance of separating entrepreneurial capital from their own capital.
\end{abstract}

Keywords: Tax. MSME, Regulation Number 23 of 2018, NPWP

\begin{abstract}
Abstrak
Pajak adalah sumber utama penerimaan negara. Pada tahun 2018, sumber penerimaan negara sebesar $85,40 \%$ berasal dari sektor pajak. Begitu besarnya, penerimaan negara dari sektor pajak, mendorong pemerintah untuk meningkatkan kepatuhan wajib pajak. Akan tetapi, realisasi penerimaan dari sektor pajak pada bulan Januari-November belum mencapai target. Pada tahun 2018, pemerintah mengeluarkan peraturan pemerintah yang diperuntuhkan untuk wajib pajak yang memiliki penghasilan bruto tertentu. Sehingga, dengan dikeluarkannya peraturan pemerintah diharapkan masyarakat lebih dapat berperan aktif dalam kegiatan ekonomi. Pengabdian ini dilakukakan di Dukuh Banjaran, Sukoreno, Sentolo, Kulon Progo, Daerah Istimewa Yogyakarta. Pengabdian ini ditunjukan untuk pelaku UMKM. Teknik pengabdian ini menggunakan metoda ceramah, sharing, dan diskusi. Hasil dari kegiatan pengabdian ini adalah meningkatkan pengetahuan pelaku UMKM mengenai perannya dalam pembangunan, meningkatkan pengetahuan pelaku UMKM mengenai manfaat NPWP, alasan pelaku UMKM harus membayar pajak, serta manfaat pajak. Selain itu, pengabdian ini juga menemukan alasan UMKM tidak membuat NPWP, serta alasan pelaku UMKM tidak menerapkan Peraturan Pemerintah Nomor 23 Tahun 2018. Selain itu, ternyata pelaku UMKM juga belum mengerti pentingnya memisahkan modal berwirausaha dengan modal sendiri.
\end{abstract}

Keywords: Pajak, UMKM, PP Nomor 46 Tahun 2018. NPWP 


\section{PENDAHULUAN}

Pajak merupakan sumber utama penerimaan negara. Hal ini terlihat pada tahun 2018, penerimaan negara dari sektor perpajakan mencapai $85,40 \%$ [1]. Begitu besarnya penerimaan negara yang berasal dari sektor pajak, maka mendorong pemerintah untuk untuk meningkatkan penerimaan negara yang bersumber dari sektor pajak. Walaupun pajak adalah sumber penerimaan negara, namun realisasi penerimaan pajak Januari-November baru sebesar 80,43\%. Namun, penerimaan tersebut sudah mengalami peningkatan $15,3 \%$ dibandingkan dengan tahun sebelumnya [2]

Tahun 2018, pemerintah mengeluarkan peraturan perpajakan baru yang diperuntuhkan untuk wajib pajak yang memiliki peredaran bruto tertentu (Peraturan Pemerintah Nomor 23 Tahun 2018). Peraturan ini menggantikan peraturan pemerintah sebelumnya, yaitu Peraturan Pemerintah Nomor 46 Tahun 2013) [3]. Perbedaan yang mendasar antara Peraturan Pemerintah Nomor 46 Tahun 2013 dengan Peraturan Pemerintah Nomor 23 Tahun 2018, yaitu adalah tarif pajaknya. Tarif yang semula $1 \%$ menjadi $0,5 \%$ [4].

Penurunan tarif ini dilandasi oleh beberapa alasan, yaitu (1) mendorong peran serta masyarakat dalam kegiatan ekonomi formal, (2) lebih memberikan keadilan, (3) mempermudah wajib pajak dalam melaksanakan kewajibannya, (4) memberikan kesempatan bagi wajib pajak untuk berkontribusi kepada negara, serta (5) memberikan pengetahuan kepada masyarakat mengenai manfaat pajak. Atau dengan kata lain, penurunan tarif ini secara tidak langsung akan meningkatkan kepatuhan wajib pajak. Oleh karena itu, penerimaan negara dari sektor pajak pun akan meningkat [4].

Berdasarkan uraian sebelumnya, maka pengabdian ini bertujuan untuk (1) mensosialisasikan peran UMKM dalam mengurangi pengangguran, serta (2) sosialisasi mengenai Peraturan Pemerintah Nomor 23 Tahun 2018. Oleh karena itu, dengan adanya sosialisasi ini diharapkan wajib pajak, khususnya pelaku UMKM dapat lebih memahami mengenai peraturan ini. Sehingga secara tidak langsung akan mendorong kesadaran pelaku UMKM untuk melaksanakan kewajiban perpajakanya. Oleh karena itu, tujuan dari penurunan tarif pajak yang dilakukan pemerintah dapat terwujud.

\section{METODE PENGABDIAN}

\section{Tempat dan Waktu}

Kegiatan pengabdian kepada masyarakat mengenai sosialisasi peran UMKM dan Peraturan Pemerintah Nomor 23 Tahun 2018 guna meningkatkan kesadaran wajib pajak dilaksanakan pada hari minggu, tanggal 09 Februari 2019. Pengabdian ini bertempat di Dukuh Banjaran, Sukoreno, Sentolo, Kulon Progo, Daerah Istimewa Yogyakarta.

\section{Objek Pengabdian}

Objek pengabdian ini adalah pelaku UMKM yang berada di Dukuh Banjaran, Sukerono, Sentolo, Kulon Progo. Pelaku UMKM adalah satu subjek dari Peraturan Pemerintah Nomor 23 tahun 2018, sepanjang UMKM tersebut masih memiliki omset tidak melebihi Rp4,8 miliar per tahun.

\section{Teknik Pengabdian}

Teknik pengabdian ini dilakukan dengan menggunakan tiga pendekatan yaitu pendekatan ceramah, sharing pengalaman, dan diskusi. Langkah yang dilakukan pada pengabdian ini adalah (1) tahap sosialisasi mengenai peran UMKM dalam pembangunan. Sehingga, hal ini dapat meningkatkan pengetahuan pelaku UMKM mengenai peran mereka dalam pembangunan negara, (2) sharing pengalaman yang dilakukan oleh pelaku usaha mengenai keuntungan dan kendala 
yang dihadapi saat menjalankan usaha. Sehingga, hal ini dapat diharapkan pelaku UMKM lebih memiliki semangat untuk mengembangkan usahanya, (3) sosialisasi perpajakan, yang meliputi alasan membuat nomor pokok wajib pajak (NPWP), alasan membayar pajak, dan manfaat pajak. Sehingga, hal ini dapat meningkatkan pengetahuan pelaku UMKM mengenai alasan pelaku UMKM harus membayar pajak, dan manfaatnya bagi negara, (4) sosialisasi mengenai cara Peraturan pemerintah Nomor 23 Tahun 2018. Sehingga, hal ini meningkatkan pengetahuan atau keahlian pelaku UMKM untuk melakukan perhitungan pajak yang sesuai dengan Peraturan Pemerintah Nomor 23 Tahun 2018.

\section{HASIL DAN PEMBAHASAN}

Salah satu teknik pengabdian yang digunakan pada pengabdian ini adalah pendekatan ceramah. Ceramah dilakukan oleh dua pemateri. Pembagian materi adalah materi yang terkait dengan perpajakan dan materi yang terkait dengan UMKM.

Materi yang terkait perpajakan meliputi manfaat dari pembuatan NPWP, alasan membayar pajak, dan manfaat pajak bagi negara. Sedangkan, materi yang terkait dengan UMKM meliputi peran UMKM dalam pembangunan, serta sharing pengalaman yang dilalui selama menjalankan usaha.

Kegiatan pengabdian berjalan sekitar 150 menit. Waktu untuk ceramah dan sharing sekitar 120 menit, dan 30 menit merupakan sesi diskusi. Pada sesi sharing dan diskusi pelaku UMKM menunjukan antusias yang baik. Pada saat diskusi dan sharing beberapa pelaku UMKM mengungkapkan alasan pelaku UMKM enggan untuk membuat NPWP, maupun alasan keenggannya untuk melaksanakan kewajiban perpajakannya.
Alasan pelaku UMKM tidak membuat NPWP adalah pelaku UMKM belum membutuhkan NPWP untuk meminjam dana ke perbankan. Sedangkan, alasan pelaku UMKM tidak melaksanakan Peraturan Pemerintah Nomor 23 Tahun 2018 [5] karena pelaku UMKM belum mengetahui bahwa mereka adalah subjek dari peraturan tersebut. Sehingga, dengan kegiatan ini pelaku UMKM lebih mengetahui bidang perpajakan.

Pelaku UMKM juga mengungkapkan bahwa selama ini mereka belum memisahkan uang (modal) berwirausaha dengan uang pribadinya. Sehingga, diharapkan pula dengan pengabdian ini pelaku UMKM lebih memahami pentingnya memisahkan uang (modal) berwirausaha dengan uang pribadi.

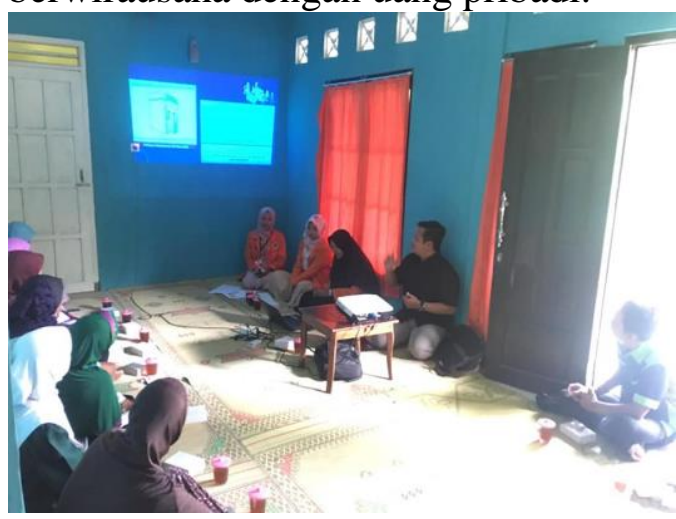

Gambar 1. Proses Sosialisasi

Kegiatan pengabdian diakhir dengan ramah tamah, dan foto Bersama peserta. Hal ini bertujuan untuk mengabdikan momen kegiatan pengabdian.

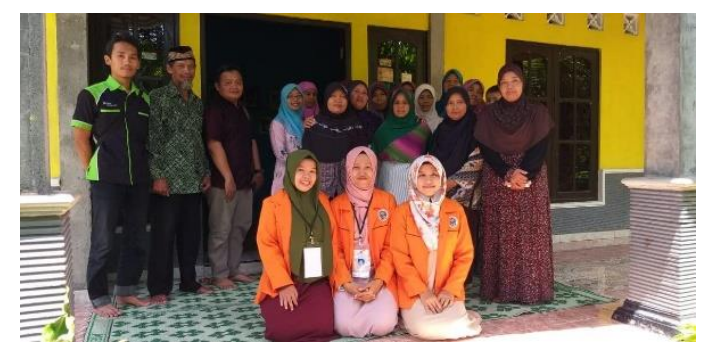

Gambar 2. Foto Bersama Peserta

\section{SIMPULAN}

Kesimpulan dari kegiatan pengabdian yang dilakukan pada hari 
minggu, tanggal 09 Februari 2019, yang bertempat di Dukuh Banjaran, Sukoreno, Sentolo, Kulon Progo, Daerah Istimewa Yogyakarta adalah sebagai berikut.

1. Kegiatan pengabdian ini dapat meningkatkan pengetahuan mengenai peran pelaku UMKM dalam pembangunan.

2. Kegiatan pengabdian ini dapat meningkatkan pengetahuan pelaku UMKM mengenai mafaat NPWP, alasan pelaku UMKM harus membayar pajak, serta manfaat pajak.

3. Kegiatan pengabdian ini menemukan alasan UMKM tidak membuat NPWP. Alasan pelaku UMKM tidak membuat NPWP karena pelaku UMKM belum membutuhkan NPWP.

4. Kegiatan pengabdian ini juga menemukan bahwa pelaku UMKM belum menyadari pentingnya memisahkan uang (modal) dari berwirausaha dan uang pribadi

5. Kegiatan pengabdian ini menemukan bahwa pelaku UMKM tidak melaksanakan Peraturan Pemerintah Nomor 23 Tahun 2018, bukan berarti mereka sengaja untuk tidak melaksanakan, namun ternyata karena ketidaktahuan mereka pada peraturan ini.

\section{UCAPAN TERIMAKASIH}

Pengabdi mengucapkan terima kasih kepada kepala dukuh dan pelaku UMKM Dukuh Banjaran, Sukoreno, Sentolo, Kulon Progo, Daerah Istimewa Yogyakarta atas izin dan partisipasi dalam kegiatan pengabdian ini. Pengabdi juga mengucapkan terima kasih kepada mahasiswa KKN Universitas Ahmad Dahlan Unit XIX.B.2 yang telah menginisiasi untuk terselanggaranya kegiatan pengabdian ini.
DAFTAR PUSTAKA

[1] Kemenkeu, "APBN KITA Kemenkeu," 2018. [Online]. Available:

https://www.kemenkeu.go.id/me dia/11152/apbn-kita-edisinovember-2018_rev.pdf. [Accessed: 10-Feb-2019].

[2] Kata Data, "Pusat Data Ekonomi \& Bisnis - Realisasi Penerimaan Pajak Januari s/d November2018," 2019. [Online]. Available:

https://databoks.katadata.co.id/da tapublish/2018/12/07/realisasipenerimaan-pajak-januarinovember-2018-mencapai-80. . [Accessed: 10-Feb-2019].

[3] S. Negara, "Peraturan Pemerintah Nomor 46 Tahun 2013 Tentang Pajak Penghasilan Atas Penghasilan Dari Usaha Yang Diterima atau Diperoleh Wajib Pajak Yang Memiliki Peredaran Bruto tertentu.," 2013.

[4] Pajak, "Direktorat Jenderal Pajak: Beranda," 2018. [Online]. Available: https://www.pajak.go.id/. [Accessed: 15-Feb-2019].

[5] S. Negara, "Peraturan Pemerintah Nomor 23 Tahun 2018 Tentang Pajak Penghasilan Atas Penghasilan Dari Usaha Yang Diterima atau Diperoleh Wajib Pajak Yang Memiliki Peredaran Bruto tertentu.," 2018. 